\title{
Visualization of cell structure by atomic force microscopy
}

\begin{abstract}
Cell structure has been extensively studied by light and electron microscopy. However, there are relatively few papers on the study of internal cell structure with the atomic force microscope. In this mini review, efforts to visualize and analyze inner cell structure with the atomic force microscope are here presented, using the technique for sample preparation derived from the standard transmission electron microscopy. Semithin sections of epon embedded samples mounted on glass slides are scanned with a microscope working on contact or intermittent modes. The surface of sections revealed internal cell structure. Animal and plant cells show structures as nuclei, nucleoli, chromatin, cell wall, mitochondria. These works opens up the perspective to analyze these organelles and structures at a nanoscale under liquid physiological conditions.
\end{abstract}

Keywords: atomic force microscopy, cell structure, nanoscale
Volume 3 Issue 5 - 2017

\author{
María de Lourdes Segura-Valdez,' Alma \\ Zamora-Cura, ${ }^{2}$ Luis $\mathrm{F}$ Jiménez-García' \\ 'Department of Cell Biology, Universidad Nacional Autónoma \\ de México (UNAM), México \\ ${ }^{2}$ National Institute of Genomic Medicine, México
}

\begin{abstract}
Correspondence: Luis F Jiménez García, Laboratorio de Nanobiología Celular Departamento de Biología Celular, Universidad Nacional Autónoma de México (UNAM), Circuito Exterior, C.U., 04510, Cd. Mx., México, Tel (55)56224988, Fax (55)56224828, Email luisfelipe_jimenez@ciencias.unam.mx
\end{abstract}

Received: December 27, 2016 | Published: June 01, 2017

\section{Introduction}

Since its invention in $1986^{1}$ atomic force microscopy (AFM) has been used to study properties of surface of materials at the nanoscale. In biological sciences, AFM has mainly been used for the study of isolated molecules and their interactions, even in real time ${ }^{2-4}$ and recently at high resolution and high speed. ${ }^{5}$ However, the use of AFM to analyze inner cell structure is scarce. The inner structure of the cell was extensively described by optical and electron microscopy ever since the discovery of cells in cork and is extensively displayed in many articles and texts. ${ }^{6} \mathrm{AFM}$ offers the opportunity of analyze several properties of the inner structure of the cell at nanoscale, included topographic characterization. In this mini-review, we revised briefly several efforts intended to visualize inner structure of cells by AFM.

The atomic force microscope is a topographic technique that would allow us to analyze entire cells, revealing only the external side of the membrane. Therefore, using sections of material processed for transmission electron microscopy was an approach that produced results. Although initial efforts were made producing images, ${ }^{7}$ material processed using epoxy resins and semithin sections stained with toluidine blue or even unstained sections, produced images with better $\mathrm{Z}$ resolution. ${ }^{8-17}$

The samples are processed by fixation with glutaraldehyde, post fixation with osmium tetroxide, dehydration with graded concentration of ethanol and embedded in epoxy resin. Semithin sections of $250 \mathrm{~nm}$ width are attached or mounted on glass slides. Surfaces of sections are observed with an AFM working in contact or tapping mode.

Results obtained over the years include samples of plant and animal cell as well as samples from unicellular parasites as Giardia lamblia and Entamoeba Histoltica. For example, the plant Lacandonia schismatica, a species with the sex organs inverted, was used as a model to test the technique, producing images similar to those obtained with the light and electron microscopes. ${ }^{8-10,13,16}$ The cell nucleus and nucleolus were recognized, as well as compact chromatin. In fact, compact chromatin visualized by AFM was used as an additional criterion for the diagnosis of reticulated chromatin in Ginkgo biloba. ${ }^{18}$
In plants, cell wall was a marker to recognize plant cell, and structure within. However, animal cell were more difficult to visualize. Using tapping mode on Hep2 cells, images of cell nuclei were obtained and nuclear structures as interchromatin granule clusters were resolved. ${ }^{17}$ Previously, nuclear particles named Lacandonia granules ${ }^{19}$ were observed individually, ${ }^{13}$ opening the possibility to analyze gene expression at the nanoscale in situ..$^{20,21}$ It is interesting to mention that aspects of cell biology as mitosis have been also studied. ${ }^{12}$

Figure 1 shows an image of a human Hep2 cell prepared for transmission electron microscopy. Semithin section was placed onto a glass slide and scanned with the AFM in tapping mode. Several internal structures are observed as cell nucleus, nucleolus, chromatin, mitochondria.

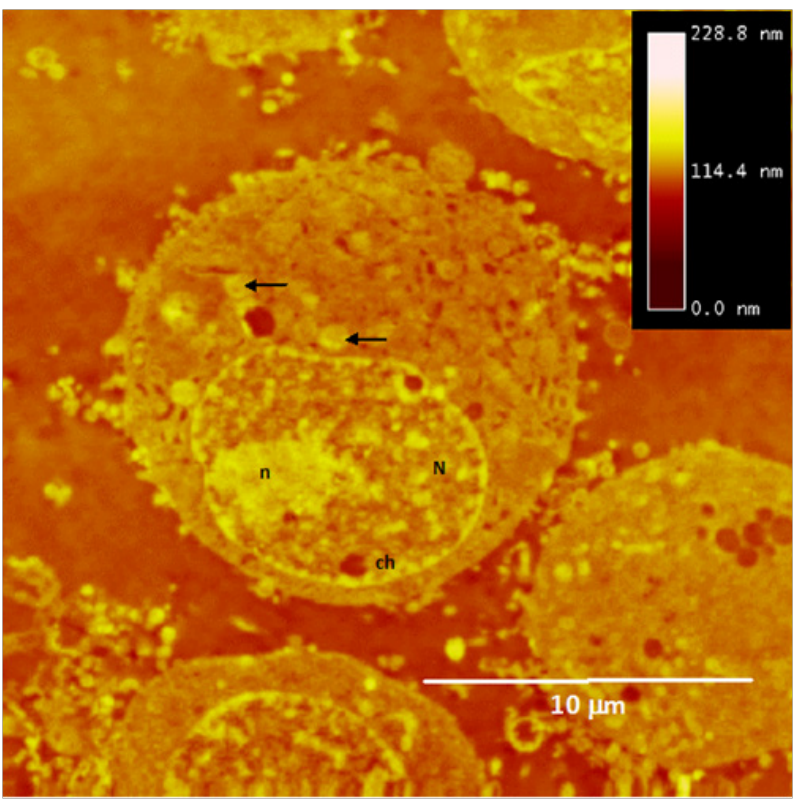

Figure I Atomic force micrograph of Hep2 cells. The cell in the center shows a large nucleus (N) and nucleolus (n) and clumps of compact chromatin (ch) In the cytoplasm, mitochondria are seen (arrows). 


\section{Discussion}

Microscopes produce images of cell that may further be analyzed. While the light and electron microscopes use lenses and a source of light or electrons, atomic force microscopes use a very fine tip that scan the sample, producing a high resolution image of the surface. Therefore, with light and electron microscopes, internal structure of cells has been possible to analyze. On the opposite, the atomic force microscope is a surface instrument. The approach mentioned in this mini review reveals also internal structure since scanning the surface of a sections, the texture correlates to cell organelles. Each section may be analyzed and every section then act as a part of internal structure. So, internal in situ cell structure can be studied by AFM. In fact, this microscope analyze the surface of the sample, therefore analysis of internal structure is initially not possible. An approach using sections of biological material and using each section as a surface, would reveal the structure present in each sections. The structure of the surface of each sections probed to be identical to the cell structure, when compared to light and electron micrographs of similar samples. Combining this approach with an AFM working in tapping mode, the resolution increases. Images are obtained similarly even if samples are observed under water or using different resins. Many biological samples can be observed now and eventually, the in situ analysis at nanoscale of processes under liquid as ribosome biogenesis, gene expression and others will be possible.

Current research mainly is focused on the understanding of biological processes at the nanoscale, as recognition of molecules and their properties with no labeling and the interaction among them..$^{22-24}$ This mini review revealed that only few papers deals with inner cell structure in situ.

\section{Conclusion}

Internal cell structure as nuclear structures can be studied in situ with the atomic force microscope using semithin sections mounted on glass slides, from biological material as plant, animal and fungi cells and also unicellular parasites as Giardia lamblia processed for standard transmission electron microscopy.

\section{Acknowledgements}

Supported by CONACyT (180835), PAPIIT-DGAPA-UNAM (IN217917), PAPIME-DGAPA-UNAM (PE213916).

\section{Conflict of interest}

Author declares that there is no conflict of interest.

\section{References}

1. Binnig G, Quate CF, Gerber Ch. Atomic force microscope. Phys Rev Lett. 1986;56(9):930-933.

2. Guthold M, Zhu C, Rivetti C, et al. Direct observation of onedimensional diffusion and transcription by Escherichia coli RNA polymerase. Biophys J. 1999;77(4):2284-2294.

3. Van Noort J, van der Werf KO, Eker APM, et al. Direct visualization of dynamic protein-DNA interactions with a dedicated atomic force microscope. Biophys J. 1998;74(6):2840-2849.

4. Van Noort J, Orsini F, Eker A, et al. DNA bending by photolyase in specific and non-specific complexes studied by atomic force microscopy. Nucl Acids Res. 1999;27(19):3875-3880.

5. Van Noort SJT, van der Werf KO, de Grooth BG, et al. High speed atomic force microscopy of biomolecules by image tracking. Biophys $J$. 1999; 77(4):2295-2303
6. Alberts B, Johnson A, Lewis J, et al. Molecular biology of the cell. New York: Garland; 2015. 1342p.

7. Ushiki T, Hitomi J, Ogura S, et al. Atomic force microscopy in histology and cytology. Arch Histol Cytol. 1996;59(5):421-431.

8. Jiménez-García LF, Reynoso-Robles R, Fragoso-Soriano R, et al. Biología Celular de Lacandonia schismatica. Análisis por microscopía electrónica y de fuerza atómica. Bol Soc Bot Méx. 1998;62:5-14.

9. Jiménez-García LF, Fragoso-Soriano R. Atomic force microscopy of the cell nucleus. J Struct Biol. 2000;129(2-3):218-222.

10. Jiménez-García LF, Segura-Valdez ML. Visualizing nuclear structure in situ by atomic force microscopy. In: Braga PC, Ricci D, editors. Atomic force microscopy: methods and protocols in biomedical applications methods in molecular medicine. New Jersey: Humana Press; 2004. p. 191-199.

11. Segura-Valdez ML, Cruz-Gómez SJ, López-Cruz R, et al. Observations on the nuclear structure of onion (Allium cepa L.) meristematic root cells by atomic force microscopy. TIP Rev Esp Cienc Quím Biol. 2006;9(1):30-33.

12. Segura-Valdez ML, Cruz-Gómez SJ, López-Cruz R, et al. Visualización de la mitosis con el microscopio de fuerza atómica. TIP Rev Esp Cienc Quím Biol. 2008;11(2):87-90.

13. Fragoso-Soriano RJ, Vázquez-López C, Pérez-García B, et al. Atomic force microscopy imaging of thin sections of Lacandonia granules. $J$ Scann Probe Microsc. 2009;4:1-5.

14. Jiménez-García LF, Zamora-Cura A, Gutiérrez-Quintanar N, et al. Análisis de la expresióngenética in situ con el microscopio de fuerzaatómica. Mensaje Bioquímico. 2010;34:157-164.

15. Segura Valdez ML, Zamora Cura A, Gutiérrez Quintanar N, et al. Visualization of cell structure in situ by atomic force microscopy. In: Méndez Vilas A, Díaz J, editors. Microscopy: science, technology, applications and education (Microscopy Book Series). Badajoz, Spain: Formatex; 2010. p. 441-448.

16. Fragoso-Soriano RJ, Jiménez-García LF, Vázquez-López C. AFM study of cellular structure organelles of Lacandonia schismatica and visualization of images using the error signal. $J$ Adv Microsc Res. 2011;6(1):1-6.

17. Zamora-Cura A, Jiménez-García LF. Visualization of interchromatin granules by atomic force microscopy. $J$ Adv Microsc Res. 2014;9(4):296-300.

18. Jiménez-Ramírez J, Agredano-Moreno LT, Segura-Valdez ML, et al. Lacandonia granules are present in Ginkgo biloba cell nuclei. Biol Cell. 2002;94(7-8):511-518.

19. Jiménez-García LF, Agredano-Moreno LT, Segura-Valdez ML, et al. The ultrastructural study of the interphase nucleus of Lacandonia schismatica (Lacandoniaceae: Triuridales) reveals a non typical extranucleolar particle. Biol Cell. 1992;75:101-110.

20. Jiménez LF, Segura ML. Biología cellular del genoma. Las Prensas de Ciencias-UNAM, Mexico City, Mexico; 2010.

21. Segura-Valdez ML, Agredano-Moreno LT, Nepomuceno-Mejía T, et al. Cell Nanobiology. In: Morales González JA, editor. Oxidative stress and chronic degenerative diseases-a role for antioxidants. Croatia: InTech; 2013.

22. Wang B, Park B, Xu B, et al. Label-free biosensing of Salmonella enterica serovars at single cell level. J Nanobiotechnol. 20017;15:40.

23. Zhou L, Cai M, Tong T, et al. Progress in the correlative atomic force microscopy and optical microscopy. Sensors (Basel). 2017;17(4):938.

24. Youssefian S, Jakes JE, Rahbar N. Variation of nanostructures, molecular interactions, and anisotropic elastic moduli of lignocellulosic cell walls with moisture. Sci Rep. 2017;7(1):2054. 